National Water-Quality Assessment Program

\title{
Geospatial Data to Support Analysis of Water- Quality Conditions in Basin-Fill Aquifers in the Southwestern United States
}

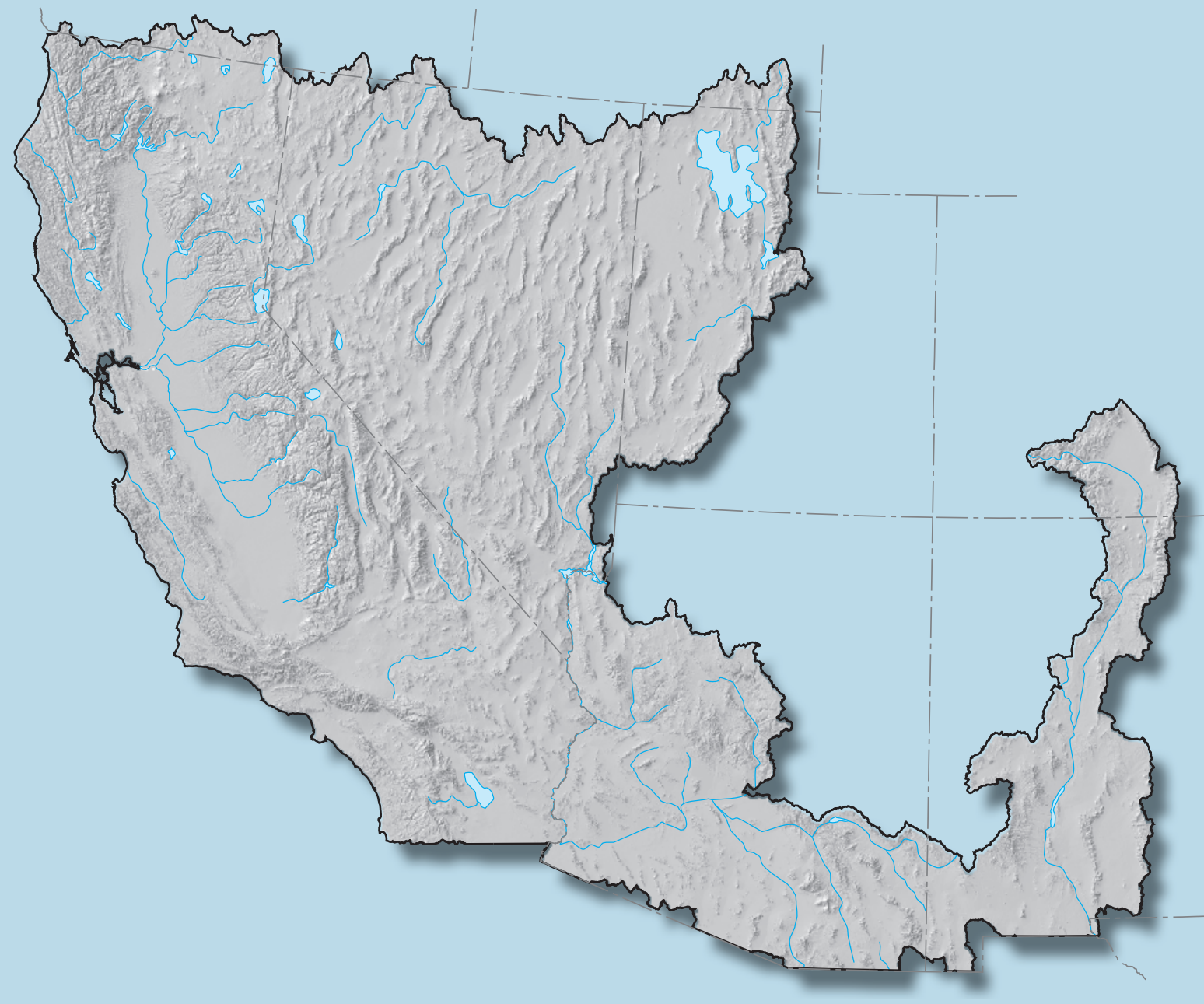

Scientific Investigations Report 2008-5239 



\section{Geospatial Data to Support Analysis of Water-Quality Conditions in Basin-Fill Aquifers in the Southwestern United States}

By Tim S. McKinney and David W. Anning

Scientific Investigations Report 2008-5239 


\title{
U.S. Department of the Interior \\ KEN SALAZAR, Secretary
}

\author{
U.S. Geological Survey \\ Suzette M. Kimball, Acting Director
}

U.S. Geological Survey, Reston, Virginia: 2009

For product and ordering information:

World Wide Web: http://www.usgs.gov/pubprod

Telephone: 1-888-ASK-USGS

For more information on the USGS - the Federal source for science about the Earth, its natural and living resources, natural hazards, and the environment:

World Wide Web: http://www.usgs.gov

Telephone: 1-888-ASK-USGS

Any use of trade, product, or firm names is for descriptive purposes only and does not imply endorsement by the U.S. Government.

Although this report is in the public domain, permission must be secured from the individual copyright owners to reproduce any copyrighted materials contained within this report.

Suggested citation:

McKinney, T.S., and Anning, D.W., 2009, Geospatial data to support analysis of water-quality conditions in basin-fill aquifers in the southwestern United States: U.S. Geological Survey Scientific Investigations Report 2008-5239, 16 p. Available at http:// pubs.er.usgs.gov/sir/2008/5239. 


\section{Contents}

Abstract
Introduction
Regional Analysis
Pata Compilation and Processing
Hydrogeologic Area Boundaries
Elevation
Geology
Land Use
Precipitation
Population
Pater Use
Public-Supply Wated Use

\section{Figures}

1. Map showing basin-fill aquifers in the Southwest Principal Aquifers study area ....... 2

2. Map showing basins studied as part of the National Water-Quality Assessment (NAWQA) program in the Southwest Principal Aquifers study area .......................... 4

3. Map showing hydrogeologic areas in the Southwest Principal Aquifers study

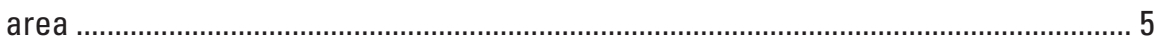

4. Map showing generalized surficial geology for the Southwest Principal Aquifers study area.

5. Map showing average annual precipitation data generated by the ParameterElevation Regressions on Independent Slopes Model (PRISM) for the Southwest Principal Aquifers study area, 1971-2000

6. Map showing public-supply water use in urban areas in the Southwest Principal Aquifers study area, 2005 .

7. Map showing estimated agricultural irrigation in the Southwest Principal Aquifers study area, 2000 .

\section{Table}

1. Example of spatial statistics derived for the National Water-Quality Assessment (NAWQA) program case-study basins in the Southwest Principal Aquifers study area 


\section{Conversion Factors and Datums}

\begin{tabular}{lcl}
\hline & Multiply & \multicolumn{1}{c}{ To obtain } \\
\hline mile $(\mathrm{mi})$ & Length & \\
\hline & 1.609 & kilometer $(\mathrm{km})$ \\
\hline acre & Area & \\
acre & 4,047 & square meter $\left(\mathrm{m}^{2}\right)$ \\
square mile $\left(\mathrm{mi}^{2}\right)$ & 0.004047 & square kilometer $\left(\mathrm{km}^{2}\right)$ \\
\hline & 2.590 & square kilometer $\left(\mathrm{km}^{2}\right)$ \\
\hline acre-foot $($ acre-ft $)$ & Volume & \\
gallon $(\mathrm{gal})$ & $1,233,489$ & liter $(\mathrm{L})$ \\
& 3.785 & liter $(\mathrm{L})$ \\
\hline gallon per day $(\mathrm{gal} / \mathrm{d})$ & Flow rate & \\
\hline
\end{tabular}

Horizontal coordinate information is referenced to the North American Datum of 1983 (NAD 83).

Vertical coordinate information is referenced to the North American Vertical Datum of 1988 (NAVD 88). 


\title{
Geospatial Data to Support Analysis of Water-Quality Conditions in Basin-Fill Aquifers in the Southwestern United States
}

\author{
By Tim S. McKinney and David W. Anning
}

\section{Abstract}

The Southwest Principal Aquifers study area consists of most of California and Nevada and parts of Utah, Arizona, New Mexico, and Colorado; it is about 409,000 square miles. The Basin-fill aquifers extend through about 201,000 square miles of the study area and are the primary source of water for cities and agricultural communities in basins in the arid and semiarid southwestern United States (Southwest). The demand on limited ground-water resources in areas in the southwestern United States has increased significantly. This increased demand underscores the importance of understanding factors that affect the water quality in basin-fill aquifers in the region, which are being studied through the U.S. Geological Survey's National Water-Quality Assessment (NAWQA) program. As a part of this study, spatial datasets of natural and anthropogenic factors that may affect ground-water quality of the basin-fill aquifers in the southwestern United States were developed. These data include physical characteristics of the region, such as geology, elevation, and precipitation, as well as anthropogenic factors, including population, land use, and water use. Spatial statistics for the alluvial basins in the Southwest have been calculated using the datasets. This information provides a foundation for the development of conceptual and statistical models that relate natural and anthropogenic factors to ground-water quality across the Southwest.

A geographic information system (GIS) was used to determine and illustrate the spatial distribution of these basinfill variables across the region. One hundred-meter resolution raster data layers that represent the spatial characteristics of the basins' boundaries, drainage areas, population densities, land use, and water use were developed for the entire Southwest.

\section{Introduction}

The Southwest Principal Aquifers study area consists of most of California and Nevada and parts of Utah, Arizona, New Mexico, and Colorado; it is about 409,000 $\mathrm{mi}^{2}$ (square mile). Basin-fill aquifers are areas of alluvial basins composed of permeable unconsolidated deposits, extend through about $201,000 \mathrm{mi}^{2}$ of the study area and are the primary source of water for cities and agricultural communities in basins in the arid and semiarid southwestern United States (Southwest). In some areas, these aquifers play a vital ecological role in providing base flow to streams supporting important aquatic and riparian habitats. Basin-fill aquifers include four of the principal aquifers of the United States (U.S. Geological Survey, 2003b): the Basin and Range basin-fill aquifers in Nevada, Utah, and Arizona; the Rio Grande aquifer system in New Mexico and Colorado; and the Coastal Basin aquifers and the Central Valley aquifer system in California (fig. 1). The study area is delineated by these southwestern principal aquifers. Withdrawals from these aquifers in 2000 accounted for more than one quarter of the total withdrawals from all aquifers in the United States for irrigation, public-supply, and self-supplied industrial water uses (Maupin and Barber, 2005).

Ground-water management plans have been established for several southwestern basins on the basis of estimated average annual recharge from natural - and in some cases artificial - sources to the aquifer system. Ground-water resources are fully appropriated with respect to legal rights in many of these basins, often at quantities much larger than the actual annual recharge amount. Human activities associated with urban and agricultural land uses can change water quality, and the effects can be exacerbated by stresses imposed on a ground-water system, such as withdrawals from wells and artificial recharge, which can accelerate and (or) change the direction of ground-water flow. Low recharge rates, long residence times, and slow rates of contaminant degradation retard cleansing of water in basin-fill aquifers; therefore, to optimally protect and use ground-water resources, it is imperative to understand the status of, trends in, and factors influencing ground-water quality. 


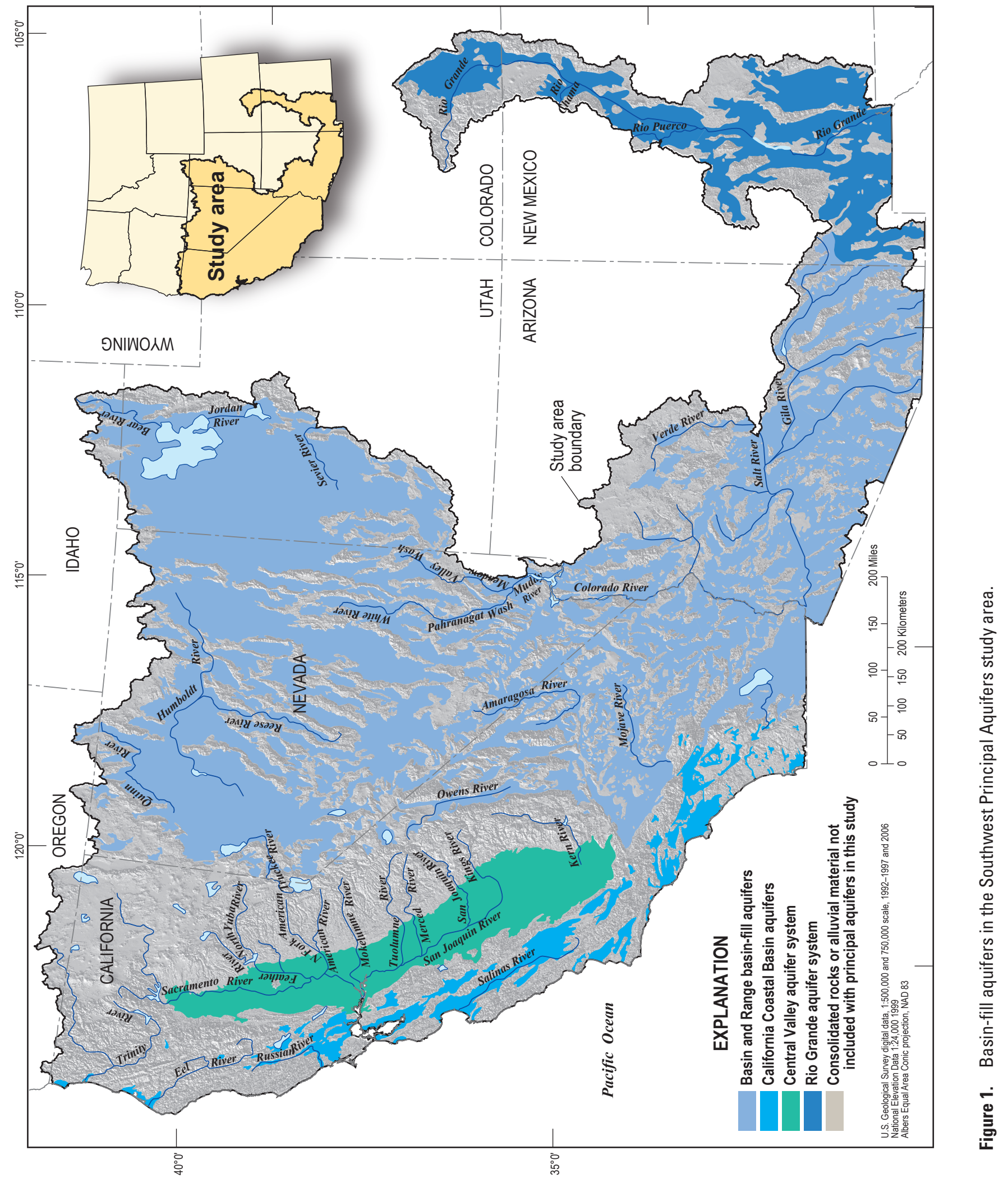




\section{Regional Analysis}

Similarities in the hydrogeology, land- and water-use practices, and water-quality issues affecting the basin-fill aquifers in the Southwest allow for a single, comprehensive regional analysis. Factors that commonly affect water quality were investigated on the basis of data and information derived from a thoroughly studied subset of basin-fill aquifers, and the relations determined from these areas can then be extrapolated to areas lacking extensive ground-water quality data and interpretive studies. Regional analysis, therefore, was a costeffective means of providing water managers with information on and insight into the status, trends, and factors affecting water quality in large, unmonitored parts of the aquifers.

The National Water-Quality Assessment (NAWQA) program of the U.S. Geological Survey (USGS) has studied the water quality in parts of selected basin-fill aquifers used for domestic and public supply in 15 basins in the Southwest (fig. 2). Data were collected primarily to characterize the ground-water quality in the aquifer by determining the occurrence and distribution of a wide suite of constituents, including major and trace elements, nutrients, pesticides, and volatile organic compounds. Although these basin-specific studies resulted in a greater understanding of local conditions and factors affecting ground-water quality, a regional assessment still is needed to synthesize the findings from these studies into a common set of factors and themes that could be applied across the basin-fill aquifers in the Southwest. More specifically, the factors that affect the fate and transport of constituents from land-surface and aquifer-matrix sources through the shallow parts of aquifers and into the deeper parts of aquifers that are commonly used for drinking-water supply need to be better understood.

\section{Purpose and Scope}

Regional analysis of factors affecting water quality in basin-fill aquifers in the Southwest requires a consistent set of data representing source, transport, and fate type variables, as well as a set of basin boundaries derived using a consistent set of criteria. These data, in addition to the water-quality data, provide a foundation for subsequent analysis through development of conceptual and statistical models. Such datasets are also valuable for other types of regional and basinscale hydrologic studies.

The purpose of this report is to document several spatial datasets developed for the regional analysis of water quality in basin-fill aquifers in the Southwest. The datasets cover the entire extent of basin-fill aquifers in the Southwest Principal Aquifers study area (fig. 1) and were collected, processed, and analyzed using consistent methods. The datasets represent natural and anthropogenic characteristics of the land surface that can either be used directly to analyze factors that affect water quality or can be used as potential surrogates for other factors in such analysis. These factors include hydrogeologic area boundaries, elevation, surface geology, precipitation, land cover, population, and water-use information. Federal Geographic Data Committee (FGDC) compliant documentation includes descriptions of the original raw data sources, processing steps, data scales, and resulting datasets.

\section{Data Compilation and Processing}

Several existing spatial datasets were compiled for this study. Datasets that represent the geology, elevation, hydrogeologic area (defined below), land cover, population, and water use were available for all or much of the study area. These datasets were processed to provide information that could be used to better understand the ground-water quality in basin-fill aquifers in the Southwest.

Geographic Information System (GIS) methods were used for processing the regional spatial data layers. GIS raster data represent variables as a matrix of cells in a continuous space. A common set of analysis-environment settings for resolution and spatial extent were configured in a GIS before data were processed to ensure accurate cell-by-cell combination of the raster data. A common cell size resolution of 100 meters by 100 meters was specified across the study area. An analysis window limits the spatial extent of the data and snaps cell data to common cell boundaries for accurate processing, and the mask allows only selected cells within the analysis window to be used for data processing. The GIS vector (point, line, or polygon feature) data layers described in this report were converted to raster data, for example, rasterized, using the common analysis environment settings. Existing raster data were resampled (change cell size), reclassified, and processed as necessary to conform to the analysis and environment settings. The following subsections explain the procedures used to yield the systematic set of spatial statistics for each of the alluvial basins in the study area.

\section{Hydrogeologic Area Boundaries}

Hydrogeologic areas (HGA) are conceptualized as basins that generally have coincident ground-water and surfacewater basin boundaries (Anning and Konieczki, 2005). The HGA surrounding an alluvial basin is considered to be the contributing drainage area to the basin-fill aquifer in the alluvial basin. HGAs were used, for this study, in calculations of spatial statistics. HGAs for the study area were compiled from earlier studies of much of the region by Anning and Konieczki (2005) and were delineated for the California Coastal Basin aquifers and Central Valley aquifer system and the Rio Grande aquifer system in New Mexico and Colorado as part of this study. The resulting polygon dataset of HGAs in the Southwest Principal Aquifers study area consists of 425 basins (fig. 3). 


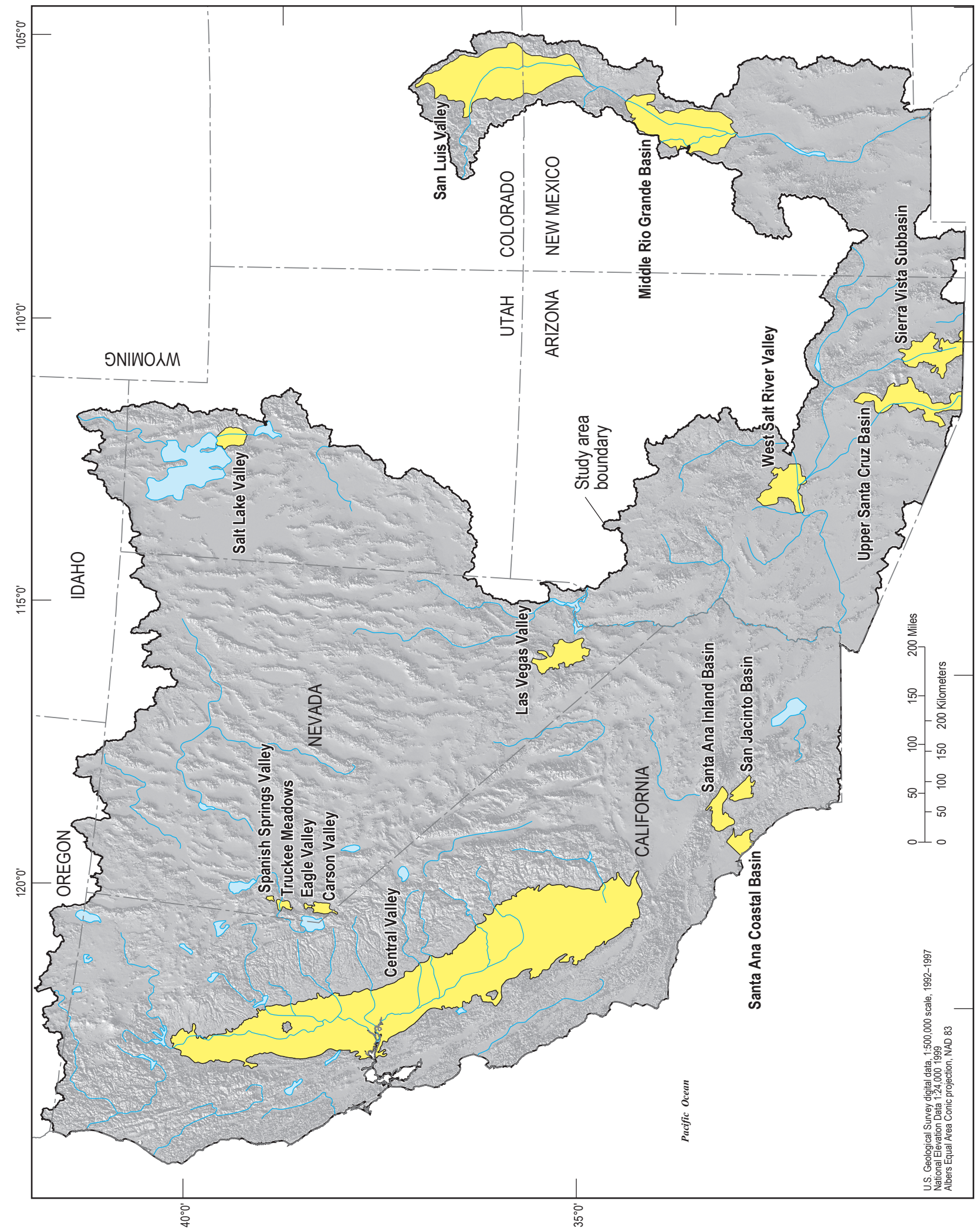

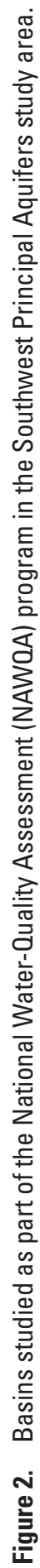




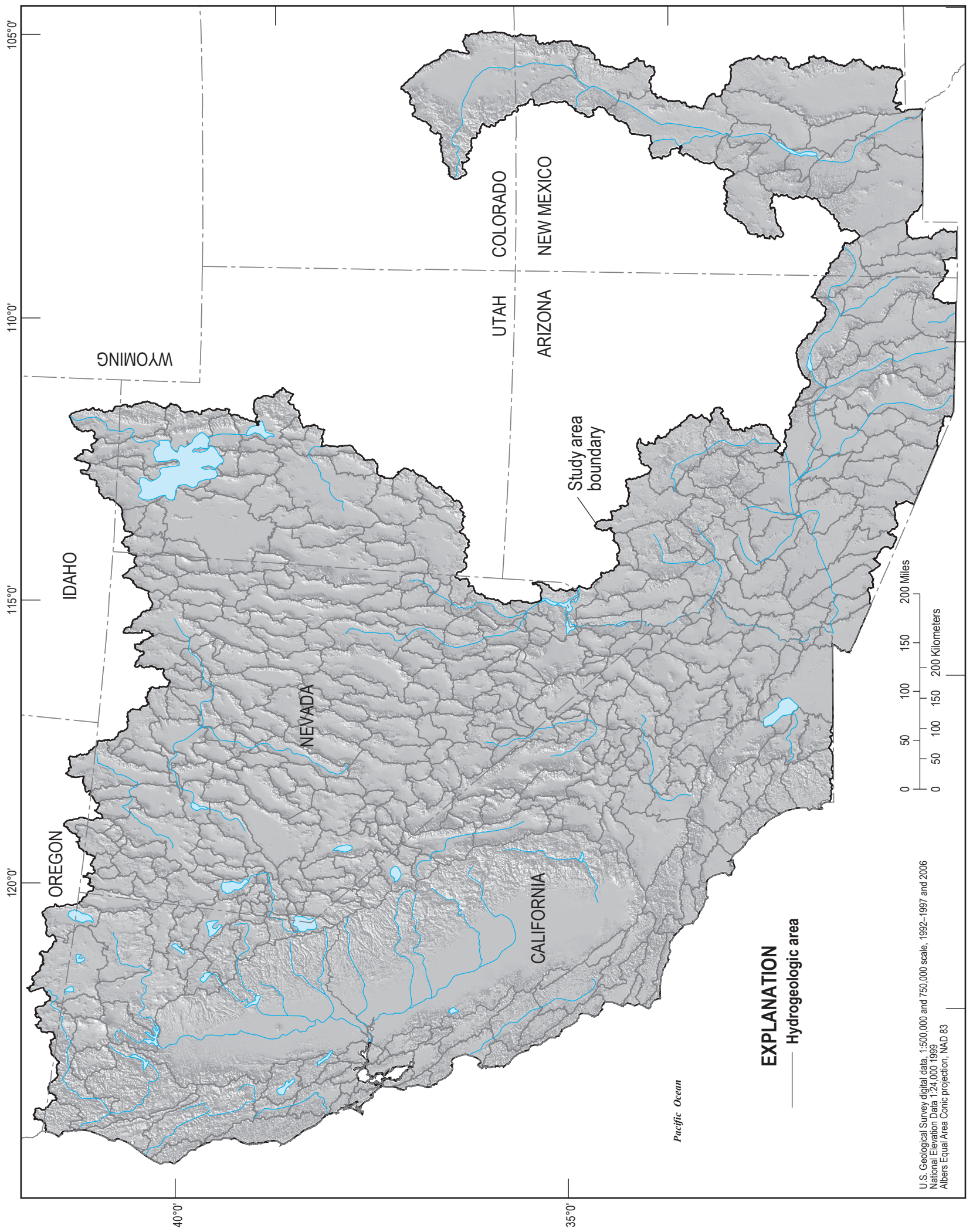

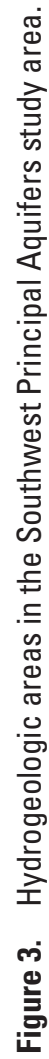


HGAs were added to areas originally defined by Anning and Konieczki (2005). The additional HGAs were delineated for parts of the Southwest outside of the original extent. The original HGA data that were acquired from the Arizona USGS Water Science Center in Tucson, Arizona, were overlaid with the California hydrologic province and watershed boundaries coverage (California Interagency Watershed Mapping Committee, 1999) and the National Hydrography Dataset (NHD) stream lines (U.S. Geological Survey, 1999b) to check for possible conflicts. HGA boundaries were modified to produce a more hydrologically consistent drainage system for areas where the basin boundary followed a stream line or otherwise was not aligned with the NHD stream dataset. The vectors used to modify the boundaries were from the Elevation Derivatives for National Applications (EDNA) catchments coverage (U.S. Geological Survey, 2005). New HGAs for the study area were delineated using the same methods as the earlier dataset.

\section{Elevation}

Digital elevation model (DEM) raster data from the USGS 30-meter (1 arc-second) National Elevation Dataset (NED) (U.S. Geological Survey, 1999a) were used to calculate land-surface slope and elevation in each cell. Slope for a cell is calculated using the rate of change in elevation for each neighboring cell. First, DEM data were hydraulically conditioned; artificial sinks and peaks were filled or leveled to remove inaccuracies resulting from errors in creating the DEM (McCoy and others, 2001). Next, the regional 2-degreeslatitude by 6-degrees-longitude DEMs were merged into a single dataset for the entire study area. Finally, slope and elevation statistics were calculated using the merged DEM for each alluvial basin and HGA.

\section{Geology}

The geologic dataset compiled for this study is a 100meter (3 arc-second) raster layer consisting of 1:750,000scale surficial geology for California (Saucedo and others, 2000) and 1:500,000-scale geology for parts of Nevada, Utah, Colorado, New Mexico, and Arizona (fig. 4). The 1:500,000-scale dataset is a modified version of existing state geologic maps that were compiled and edge matched as part of the Southwest Regional Gap Analysis Program (SW ReGAP) (RS/GIS Laboratory, 2004) and state geologic maps of parts of Oregon (Walker and others, 2003) and Idaho (Johnson and Raines, 1996). The lithologic classifications developed for the SW ReGAP geology dataset are aeolian, carbonate, evaporite, metamorphic or igneous, sandstone, sedimentary, and Quaternary alluvium; these classifications were generalized for this raster dataset. For example, shale, siltstone, and sandstone were combined into one category called sedimentary formations (RS/GIS Laboratory, 2004).

\section{Land Use}

The National Land Cover Database (NLCD) dataset for 2001 (U.S. Geological Survey, Multi-Resolution Land Characteristics (MRLC) Consortium, 2003a) was used to represent the extent of agricultural land use and rangeland cover in the study area. The NLCD is a dataset produced by the Multi-Resolution Land Characteristics (MRLC) Consortium of nine federal agencies and is a 30-meter cell resolution raster dataset of land cover for the entire United States (Homer and others, 2004). The data were generated from Landsat 5 Thematic Mapper (TM) and Landsat 7 Enhanced Thematic Mapper Plus (ETM+) satellite imagery in 2001 and depict 29 classes of land-cover data. The NLCD is a nationally consistent, 30-meter resolution dataset representing natural land cover and anthropogenic land use. NLCD data were also used to distribute county-level irrigated agricultural water use to individual raster cells within the study area.

\section{Precipitation}

The Oregon State University Parameter-Elevation Regressions on Independent Slopes Model (PRISM) dataset was used to assign precipitation values to basins across the study area. The approach used to generate the PRISM dataset combined weather station and elevation data to create modeled monthly and annual precipitation raster layers by using weighted weather station climate data and linear elevation regressions in an iterative process. Because the available station data may not represent conditions for the surrounding locations, the linear regression was modified for each model cell to reflect changes in climate and elevation. Average annual precipitation data for 1971-2000 (PRISM Group, Oregon State University, 2004) (fig. 5) generated by PRISM were used to develop basin statistics.

\section{Population}

LandScan global population raster data for 2005 were used to represent the extent of urban areas within the study area and to disaggregate county-level public-supply water use. The LandScan dataset was developed by Oak Ridge National Laboratory for the United States Department of Defense. LandScan data are produced at the U.S. Census Block level and modified using photographic interpretation, image analysis and population modeling (Oak Ridge National Laboratory, 2005). 


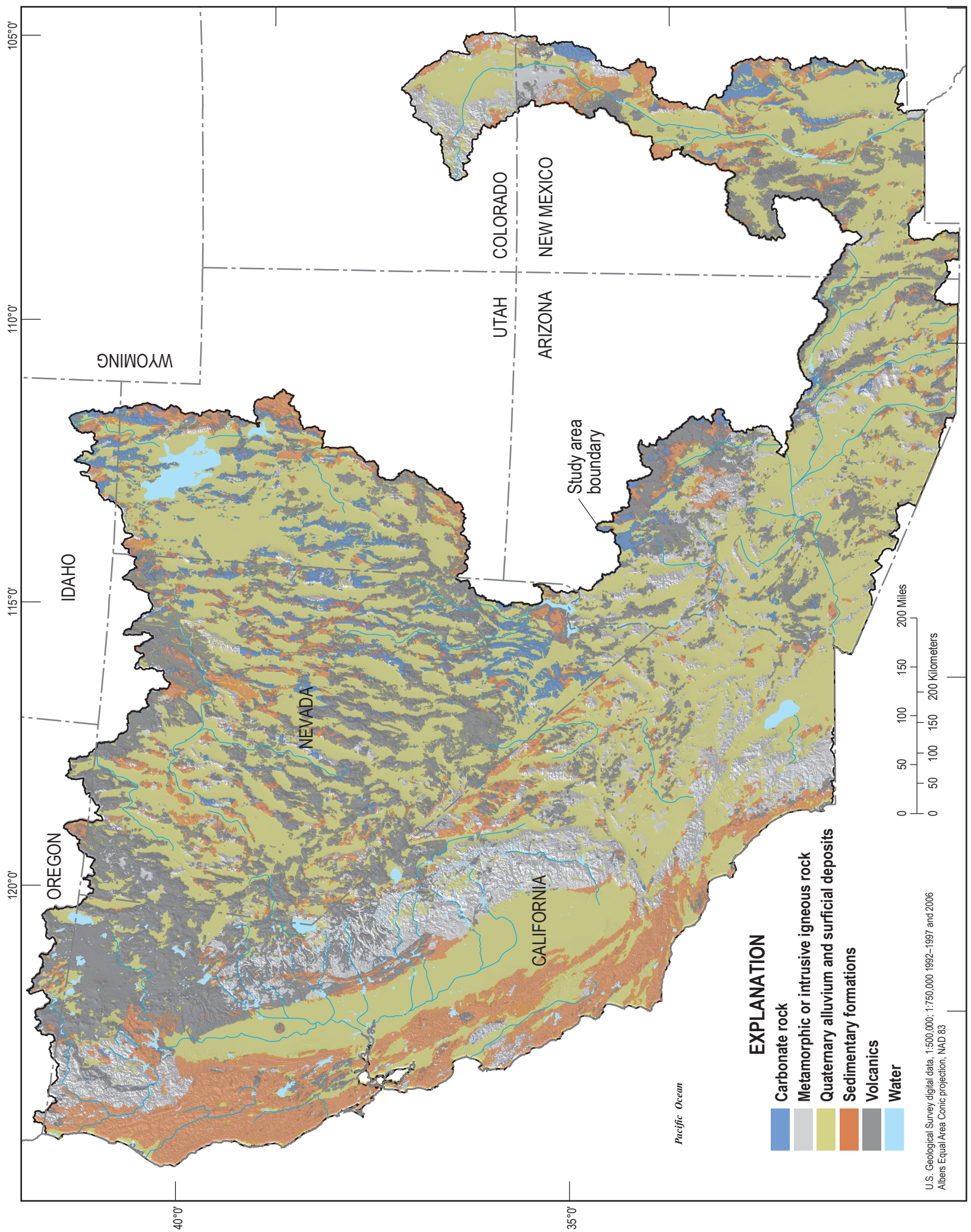

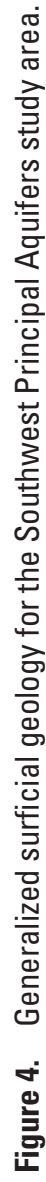




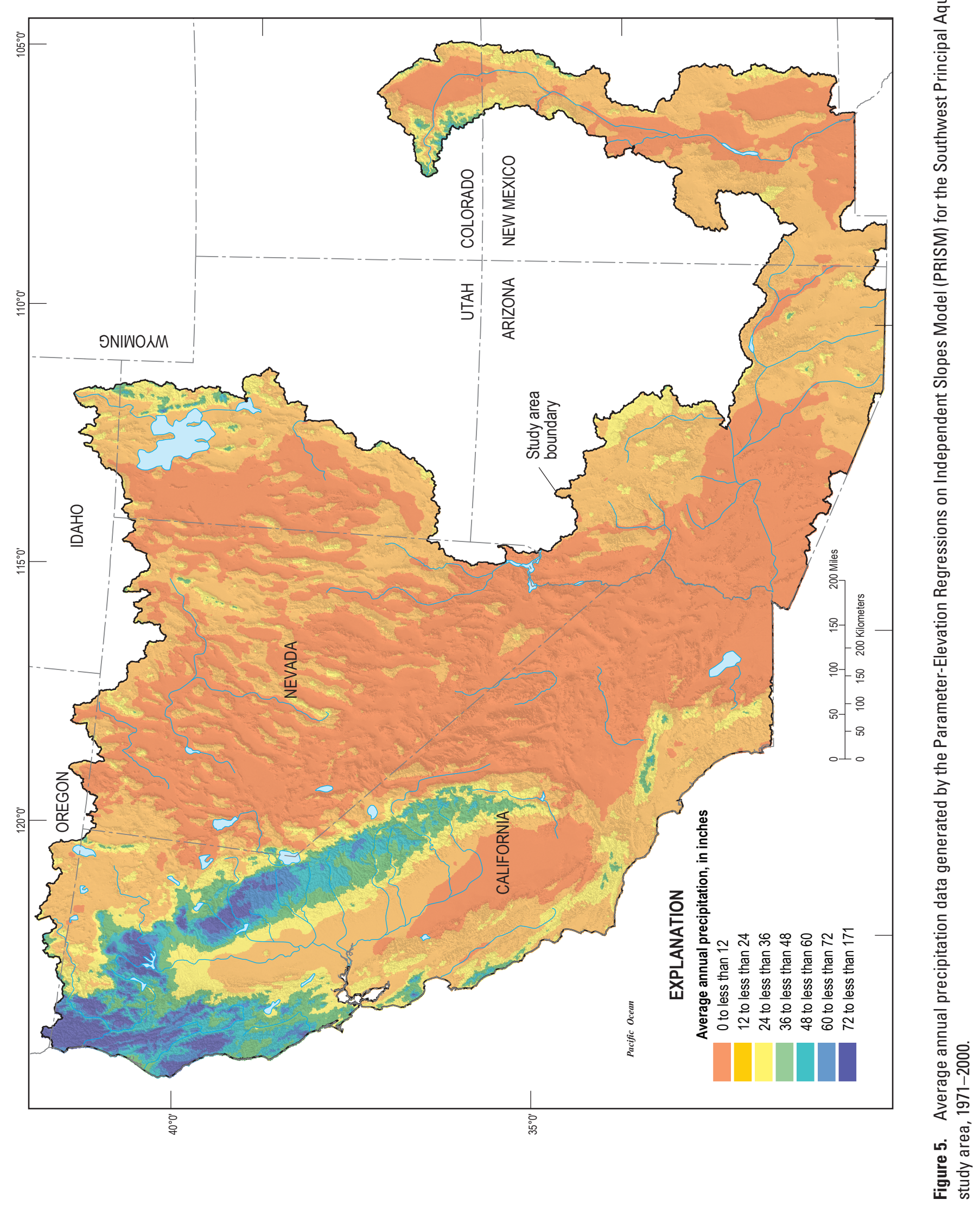




\section{Water Use}

The USGS county-level Estimated Use of Water in the United States in 2000 was the basis for developing the estimated public-supply and irrigated-agriculture water-use raster datasets for the Southwest Principal Aquifers study area. The original dataset was compiled nationally using consistent methods for determining county-level water use (Hutson and others, 2004). The USGS water-use program (http://water.usgs. gov/watuse/) has compiled these data every 5 years since 1950 and provides estimates of thermoelectric power, industrial, public supply, and agricultural water use in the Nation.

\section{Public-Supply Water Use}

The data layer containing estimated public-supply water use in 2005 is a 100-meter (3-arc-second) cell resolution raster of disaggregated county-level public-supply water-use data for the study area (fig. 6). The data layer was generated from spatially distributed LandScan population data for 2005 (Oak Ridge National Laboratory, 2005), 1:100,000-scale county boundaries, and year-2000 tabular data for per capita water use by county estimated by the USGS (U.S. Geological Survey, 2004) This dataset represents the spatial distribution of urban areas, population, and public-supply water use for the year 2005 in the Southwest.

LandScan population density raster data was derived by dividing the LandScan population raster data by a raster area dataset (eq 1). The population density raster was then resampled to a common cell resolution of 100 meters. For the purposes of this study, urban areas are defined as areas with more than 386 persons $/ \mathrm{km}^{2}$ and were selected from the population density raster. The new urban population density raster was combined with a rasterized county Federal Information Processing Standard (FIPS) polygon dataset (U.S. Census Bureau, 2000), which yielded a new raster dataset in which each cell contained urban population density and county FIPS codes. USGS water-use data were joined to the urban population density grid using the FIPS codes.

LandScan population $/$ raster area $=$ population density, in persons per $\mathrm{km}^{2}$

At the time of processing (2007), LandScan data were available only for the year 2005, and USGS water-use data for 2005 had not been finalized. For this study, per capita rates of water use were assumed to remain unchanged from 2000 to 2005. Therefore, 2000 water-use data and 2005 population data were combined.

Because of a lack of regional public-supply water-use spatial data, public-supply water use was disaggregated over urban areas using county per capita public-supply water-use rates.

County public-supply water use / Population in county
Only urban areas were assumed to use public-supply water. County per capita water-use rates in gallons/day/person were multiplied by the population in each cell to calculate public-supply water use by cell in gallons per day (fig. 6).

$$
\begin{aligned}
& \text { urban population density }\left(\text { persons per } \mathrm{km}^{2}\right) \times .01= \\
& \text { population per } 100 \text {-meter cell }
\end{aligned}
$$

Population and public-supply water-use estimates were compared with available estimates from various municipalities. Although most year-2005 water-use totals for metropolitan areas were not available at the time of comparison, per capita and total use data were available for earlier time periods.

\section{Irrigated Agriculture Water Use}

The estimated agricultural irrigation dataset in 2000 was created as a 100-meter (3-arc-second) cell resolution raster dataset from three sources for the nearest year available: 1:100,000-scale county boundary data, 30-meter NLCD raster data for 2001, and USGS county-based Estimated Use of Water in the United States in 2000 tabular data (USGS, 2004). The dataset represents regional-scale estimated irrigated agriculture acreages and water-use quantities (fig. 7).

The first step in creating the estimated irrigation dataset for 2000 was to select cultivated crops and pasture/hay, represented by raster values 81 and 82 , respectively, from the NLCD 2001 dataset and resample to create a new 100-meter resolution agricultural land-use raster dataset. The analysis environment settings were set for extent, mask, and cell size of the NLCD agricultural land use dataset to limit processing to the areas of NLCD agriculture. The county boundary polygon data set (U.S. Census Bureau, 2000) was then rasterized within this analysis environment using the county FIPS code and Map Algebra (McCoy and others, 2001) to create a 100-meter resolution raster dataset of county FIPS codes for agricultural areas represented in the NLCD. Tabular USGS county-based water-use data (U.S. Geological Survey, 2004) were joined to the NLCD agricultural land use-FIPS raster by the FIPS code. By joining water-use tabular data to the agricultural land-use raster data, new attribute fields could be calculated on the basis of the joined table fields. Dividing irrigated acreages and gallons withdrawn for each county by the cell count in that county yielded per cell values of irrigated acreages and gallons used per cell per day. Finally, irrigated agricultural attributes were multiplied by 100 and rounded to the nearest integer to reduce file size and to facilitate additional raster analysis. Many GIS analysis tools require integer input data. Floating point data results in larger file sizes that require more hard disk space and memory.

For this study, all agricultural crops in the Southwest were assumed to be irrigated. USGS county-based wateruse data (U.S. Geological Survey, 2004), reports irrigated acreages from the U.S. Department of Agriculture Census of Agriculture (U.S. Department of Agriculture, 1997). Data 


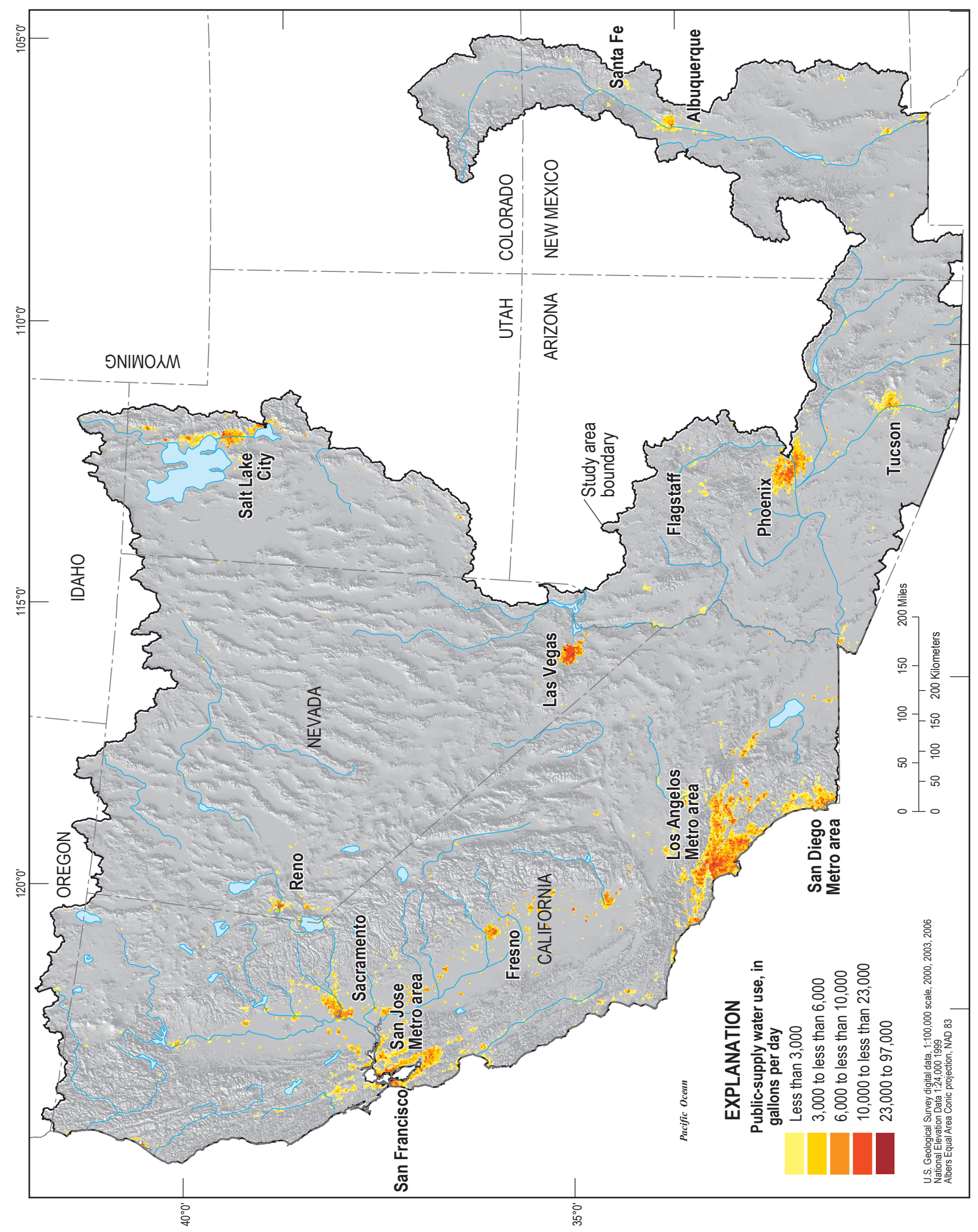

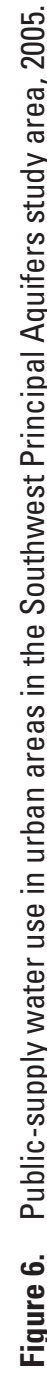




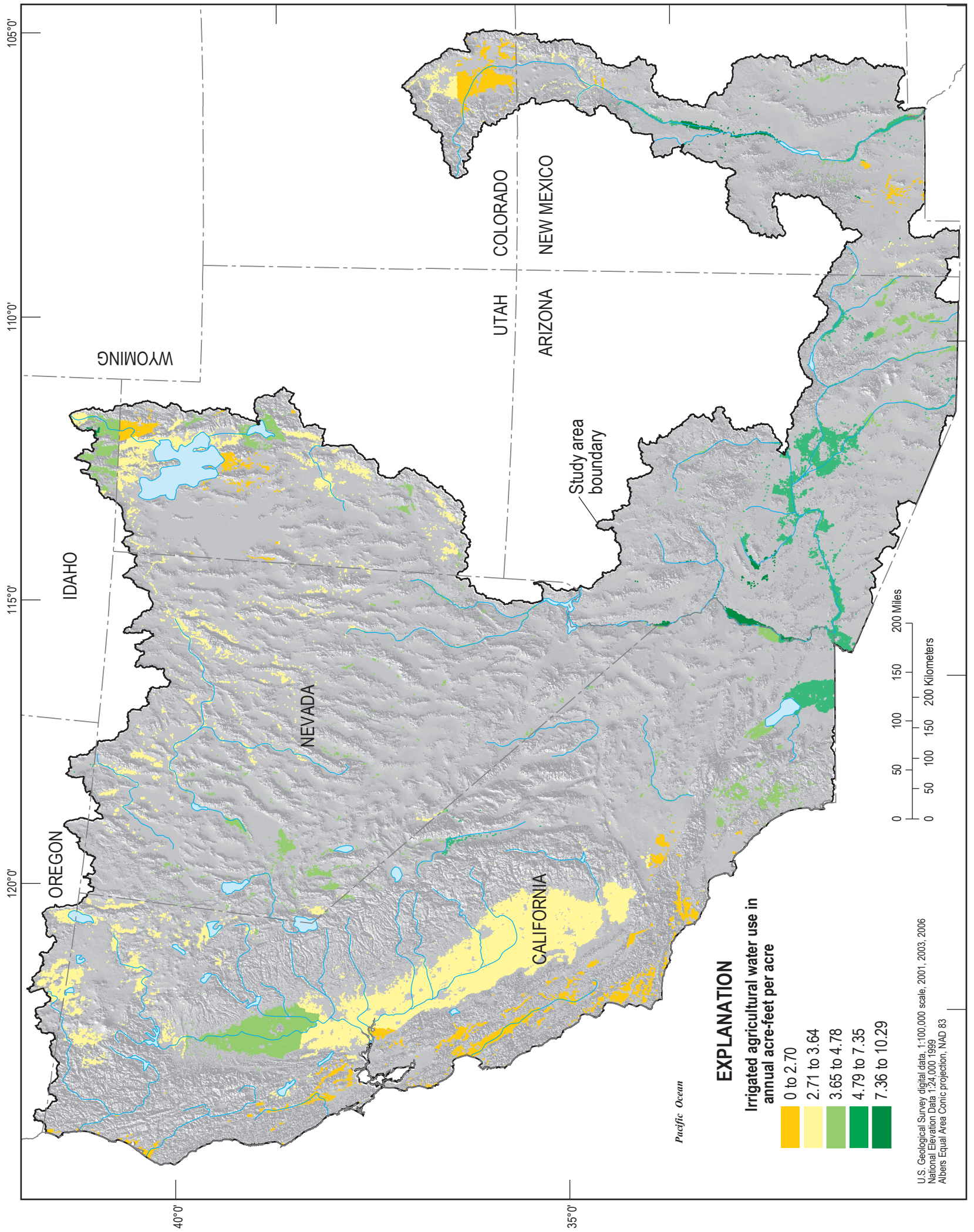

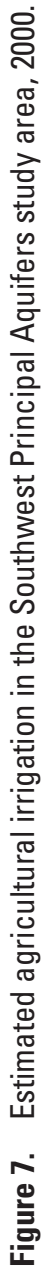


from the Census of Agriculture for irrigated acreage provide a more accurate report of agricultural land use than calculations made from individual NLCD raster cells and were used in the analysis for calculating irrigated acres. Water use and irrigated acres were distributed evenly over all NLCD agricultural land in a county rather than by individual fields. Thus, artificial discrete water-use boundaries are present at county lines as an artifact of the disaggregation process. Additionally, with this process, water may be distributed to some areas where agricultural land is misclassified by NLCD or is not in fact irrigated. Because information on the method type of irrigation, such as flood or sprinkler, was not consistently available for the entire Southwest, no attempt was made to distribute irrigation water use according to irrigation method.

Spatial accuracy of the irrigation dataset is assumed to be approximately the same as that of the original NLCD cultivated land cover. Published NLCD accuracy estimates are 81 percent error of omission, absent when predicted, and 79 percent error of commission, predicted, but absent (Homer and others, 2004).

\section{Spatial Statistics for Hydrogeologic Areas and Alluvial Basins}

Spatial analysis of the surficial geology, elevation, land cover, population, precipitation, and water use data layers yielded a dataset of spatial statistics for the HGAs and alluvial basins in the Southwest Principal Aquifer study area (fig. 1, table 1). Calculating zonal statistics involves combining a zone layer (for example, an alluvial basin) with one or more value layers (for example, geology, elevation, land cover, population, precipitation, and water use) to calculate statistics for an individual zone based on the layer value in that zone. Layer values for these statistics are available for all of the alluvial basins in the study area (425 basins). Alluvial basins can be compared to determine whether they vary across a large or small range in individual variables or combinations of variables. Data for NAWQA case-study basins of the Southwest Principal Aquifer study area were combined with the geospatial datasets to create the dataset shown in table 1. Spatial analysis of these variables highlights areas where natural and human influenced factors are similar.

\section{Summary}

Basin-fill aquifers of the arid and semiarid Southwest are an important source of water for many urban and agricultural communities. High withdrawals combined with human influence stemming from urban and agricultural land use increases the potential for water quality in basin-fill aquifers to be adversely affected. Regional effects on water quality are being studied by the U.S. Geological Survey's
National Water-Quality Assessment (NAWQA) program. Spatial datasets of natural and anthropogenic factors that may affect ground-water quality in the basin-fill aquifers of the southwestern United States have been developed as part of this study. These datasets include physical characteristics of the region, such as geology, elevation, and precipitation, as well as anthropogenic factors, including population, land use, and water use. Spatial statistics for the alluvial-fill basins in the Southwest are calculated from these datasets. This information provides a foundation for evaluating factors affecting groundwater quality across the Southwest through the development of conceptual and statistical models.

A geographic information system (GIS) has been used to determine and illustrate the spatial distribution of these basinfill variables across the region. One-hundred-meter raster data layers representing the spatial characteristics of the basins' boundaries, drainage areas, population density, land use, and water use have been developed for the entire Southwest.

\section{References Cited}

Anning, D.W., and Konieczki, A.D., 2005, Classification of hydrogeologic areas and hydrogeologic flow systems in the Basin and Range physiographic province, southwestern United States: U.S. Geological Survey Professional Paper 1702, 44 p., 2 sheets.

California Interagency Watershed Mapping Committee, 2000, The California Spatial Information Library, California Interagency Watershed Map of 1999 (CalWater 2.2.1), accessed March 17, 2006, at http://gis.ca.gov/casil/ hydrologic/watersheds/calwater.

Homer, C., Huang, C., Yang, L., Wylie, B., and Coan, M., 2004, Development of a 2001 national landcover database for the United States: Photogrammetric Engineering and Remote Sensing, v. 70, no. 7, p. 829-840.

Hutson, S. S., Barber, N. L., Kenny, J. F., Linsey, K. S., Lumia, D. S., and Maupin, M. A., 2004, Estimated use of water in the United States in 2000: U.S. Geological Survey Circular 1268, 46 p. (Also available at http://pubs.usgs.gov/ circ/2004/circ1268).

Johnson, B.R., and Raines, G.L., 1996, Digital representation of the Idaho state geologic map: a contribution to the Interior Columbia River Basin Ecosystem Management Project: U.S. Geological Survey Open-File Report 95-690, scale 1:500,000.

Maupin, M.A., and Barber, N.L., 2005, estimated withdrawals from principal aquifers in the United States, 2000: U.S. Geological Survey Circular 1279, 46 p. 
McCoy, J., Johnston, K., Kopp, S., Borup, B., and Willison, J., 2001, Using ArcGIS TM Spatial Analyst: Redlands, California, Environmental Systems Research Institute, 232 p.

Oak Ridge National Laboratory, 2005, LandScanTM Global Population Database, accessed September 2006, at http:// www.ornl.gov/landscan/.

RS/GIS Laboratory, 2004, Southwest region geology data (1:500,000 scale): College of Natural Resources, Utah State University, accessed January 2006, at http://earth.gis.usu. edu/swgap/geology.html

Saucedo, G. L., Bedford, B. R., Raines, G. L., Miller, R. J., and Wentworth, C. M., 2000, Modified from California Division of Mines and Geology, CD-ROM 2000-007, GIS data for the geologic map of California

PRISM Group, Oregon State University, 2004, Precipitationelevation Regression on Independent Slopes Model (PRISM), Oregon State University, accessed on April 2005, at $h t t p: / / w w w . o c s . o r e g o n s t a t e . e d u / p r i s m /$.

U.S. Census Bureau, 2000, 1:100,000-scale Census 2000 county and county equivalent areas cartographic boundary files, accessed December 2007, at http://www.census.gov/ geo/www/cob/co2000.html.

U.S. Department of Agriculture, National Agricultural Statistics Service, 1997, The census of agriculture. (Also available at $h t t p: / / w w w . a g c e n s u s . u s d a . g o v /$ Publications/1997/index.asp)
U.S. Geological Survey, 1999a, National Elevation Dataset, accessed January 2006, at http://ned.usgs.gov/.

U.S. Geological Survey, 1999b: U.S. Geological Survey web site, accessed March 17, 2006, at http://edna.usgs.gov/.

U.S. Geological Survey, Multi-Resolution Land Characteristics (MRLC) Consortium, 2003a, National Land Cover Database 2001, accessed February 2007, at http:// www.mrlc.gov/.

U.S. Geological Survey, 2003b, Principal aquifers of the 48 conterminous United States, Hawaii, Puerto Rico, and the U.S. Virgin Islands: U.S. Geological Survey National Atlas: U.S. Geological Survey web site, accessed October 2005, at http://www.nationalatlas.gov/mld/aquifrp.html.

U.S. Geological Survey, 2004, Estimated use of water in the United States; county-level data for 2000: U.S. Geological Survey web site, accessed online [date] at http://water.usgs. gov/watuse/data/2000/index.html

U.S. Geological Survey, 2005, Elevation derivatives for national applications (EDNA): U.S. Geological Survey web site, accessed March 2006, at http://edna.usgs.gov/.

Walker, G.W., MacLeod, N.S., Miller, R.J., Raines, G.L., and Connors, K.A., 2003, Spatial digital database for the geologic map of Oregon: U.S. Geological Survey Open-File Report 2003-67, scale 1:500,000.

\section{The results of this study are linked below:}

Estimated Irrigated Agricultural Water Use In 2000

http://water.usgs.gov/lookup/getspatial?sir2008-5239_swpa_agir_wu_2000

Aluvial basin statistics of the Southwest Principal Aquifers (SWPA) study

http://water.usgs.gov/lookup/getspatial?sir2008-5239_swpa_basin_stats

Surficial geology of the Southwest Principal Aquifers (SWPA) study

http://water.usgs.gov/lookup/getspatial?sir2008-5239_swpa_geo

Hydrogeologic Areas of the Southwest Principal Aquifers (SWPA) study (sw_hga08)

http://water.usgs.gov/lookup/getspatial?sir2008-5239_swpa_hga

Estimated Public Supply Water Use of the Southwest Principal Aquifers (SWPA) study in 2005

http://water.usgs.gov/lookup/getspatial?sir2008-5239_swpa_public_supply_wu_2005 


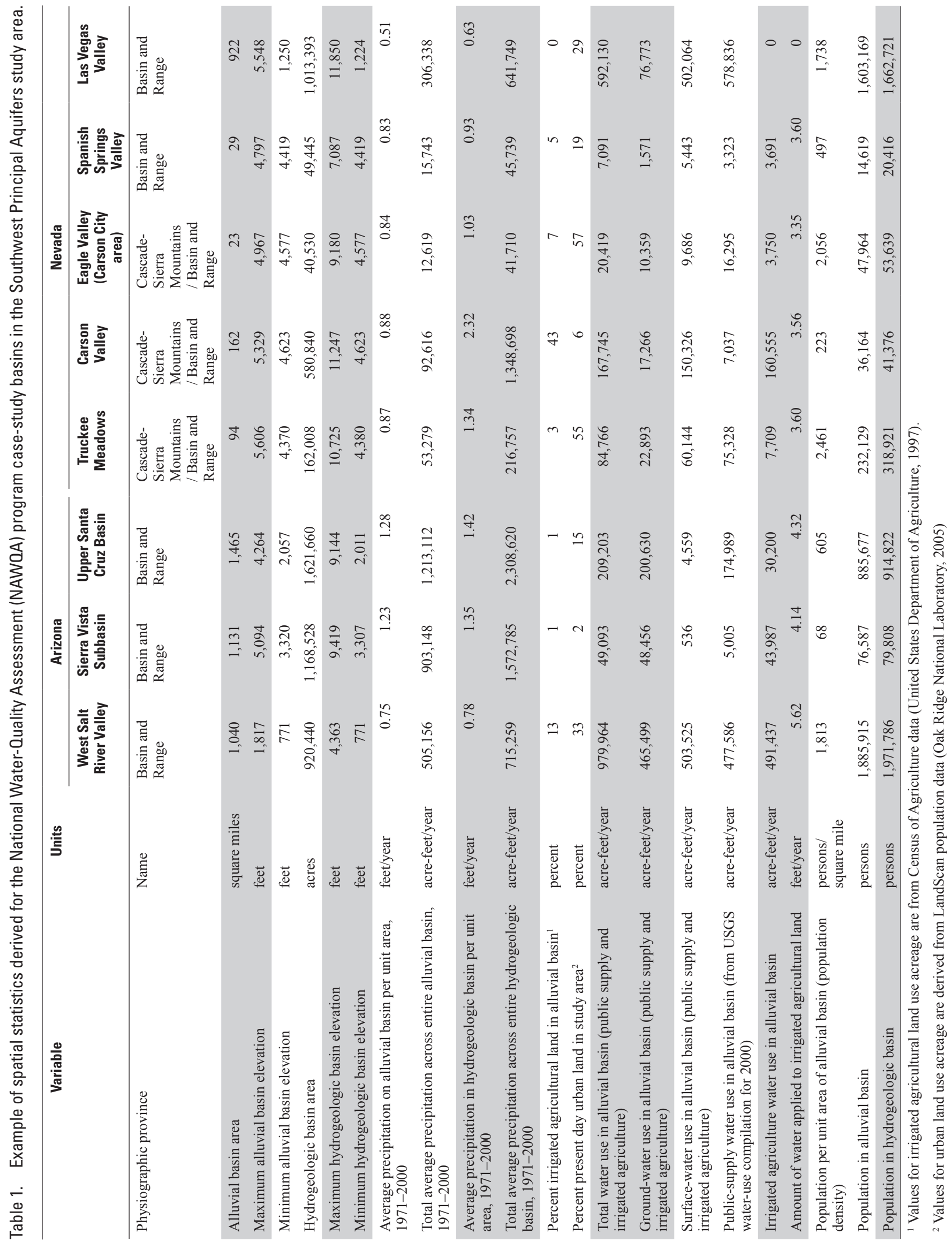




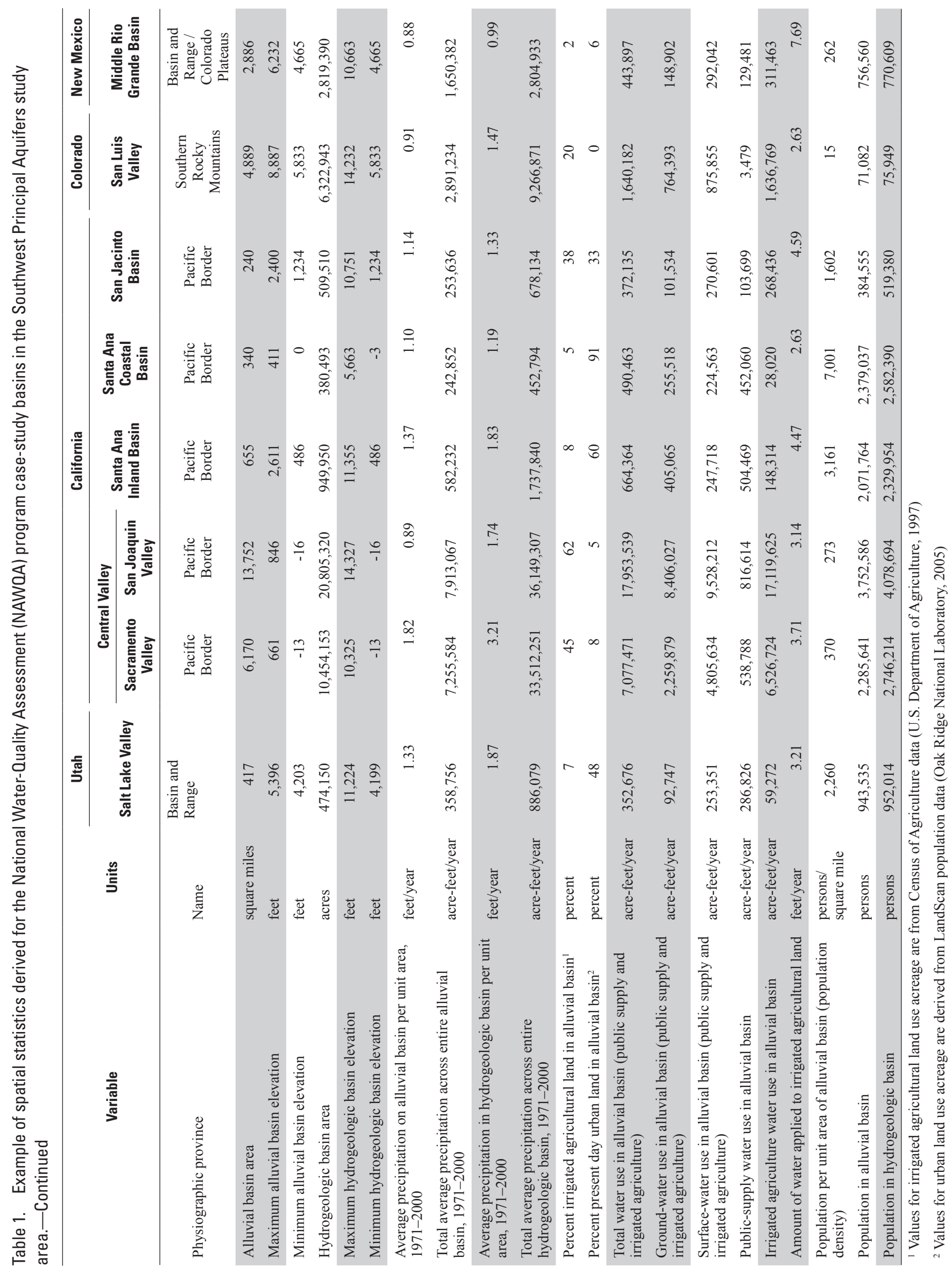





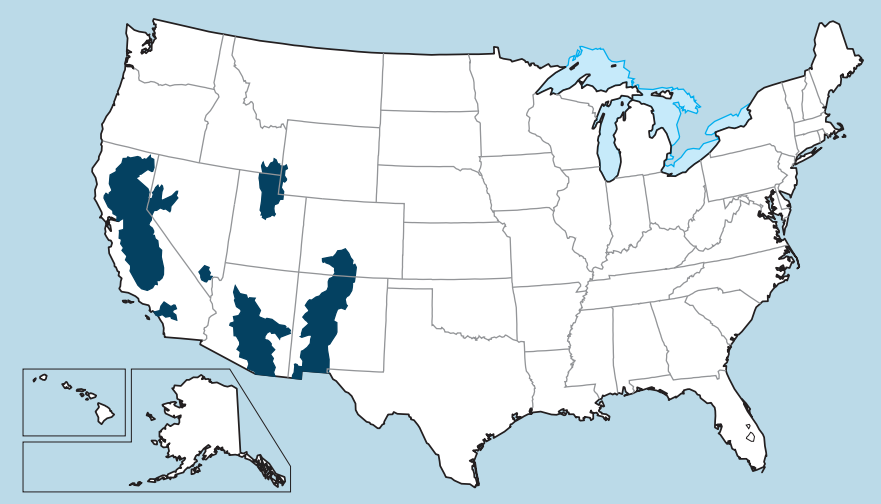

